\title{
Savings, Inflation and Economic Growth Linkages: A Re-Examination with Nigeria Data
}

\author{
Richardson Kojo Edeme, Innocent Ifelunini \\ Department of Economics, Faculty of Social Science, University of Nigeria, Nsukka, Enugu State-Nigeria
}

Email address:

richard.edeme@unn.edu.ng (R. K. Edeme), kojodynamics@yahoo.com (R. K. Edeme), innocent.ifelunini@unn.edu.ng (I. Ifelunini)

To cite this article:

Richardson Kojo Edeme, Innocent Ifelunini. Savings, Inflation and Economic Growth Linkages: A Re-Examination with Nigeria Data. Journal of Investment and Management. Vol. 4, No. 5, 2015, pp. 180-185. doi: 10.11648/j.jim.20150405.16

\begin{abstract}
The inter-relationship among savings, inflation and economic growth is an important conjuncture in the linkage evaluation of economic performance. Towards making them sustainable, the Nigeria government has initiated reforms, some of which in the last seven years. Despite these reforms, no study has been undertaken on the linkages among these variables with existing studies having confided themselves to looking only at the relationship between inflation and investment and the impact of inflation and economic growth. Using annual time series data from 1980-2013, this study examined the linkages among savings, inflation and economic growth in Nigeria using the 2-stage least squares (2SLS) method. The study found inflation and real interest to be negatively related with economic growth while exchange rate has positive effect on economic growth. Also economic growth, unemployment and real interest rate negatively affected inflation rate, while indirect taxes had positive impact on inflation. The result further shows that economic growth; exchange rate and foreign direct investment engender savings while depreciation rate endangers savings. The study also established threshold level of 8 percent of inflationary level was found to be consistent with Nigeria growth; beyond this point inflation will endanger growth.
\end{abstract}

Keywords: Savings, Inflation, Economic Growth, Investment, Interest Rate, 2-Stage Least Squares

\section{Introduction}

The Nigeria growth experience in the last decade has generated keen interest among economists and policy makers. This is because while variables such as inflation and foreign exchange rate has been on the rise, others such as savings, external reserve, real growth and total investment have been on the decline and in some cases increased marginally. For instance, in 2002 real gross domestic product (GDP) growth was 21.2 percent which declined to 10.3 percent in $2003,5.4$ percent in 2005. In 2011 and 2012, it was 7.2 percent and 7.1 percent respectively. Despite various monetary policies introduced by Central Bank over the years, Nigeria's inflation experience since 1980 has been mixed. A review of inflationary data shows that in the period from early 1980 s to the second quarter of the 1990s, annual inflation has averaged around 20 percent. Subsequently, average annual inflation came down to one-digit rate. However, since 2001, inflation is back in the two-digit rate territory with an average of about 10 percent over 2000-2002. It has also been observed that the savings rate was high from 1999-2004 (17.61 percent of total GDP) while it remained low in the period of 2005-2011, representing 5.81 percent of GDP (NBS 2012).

An examination of the inter-relationship among savings, inflation and economic growth is imperative because it is an important conjuncture in the linkage evaluation of economic performance of a country. In Nigeria, towards making them sustainable, government has initiated series of reforms, some of which in the last seven years. Despite these reforms, no study has been undertaken on the linkages among these variables with existing studies having confided themselves to looking only at the relationship between inflation and investment and the impact of inflation and economic growth. This gap will be filled by this study by taking a linkage view of savings, inflation and economic growth. This will make it possible to analyze the interactions, links and coordination among these variables. Adopting a linkage approach reinforces the fact that savings, inflation and economic growth should not be seen and considered in isolation. They work simultaneously to determine the pace of development. This means, for instance, that government cannot lose sight of the need to encourage savings and reduce inflation as it exerts improvement in investment and growth. Indeed, a linkage approach highlights that complementary policy are 
needed to promote savings and investment. International experience shows that combining domestic investment and savings can generate employment and dependency ratio (1PAR 2014). However, the concern is to provide a suite of complementary role to saving and investment as it is the synergy between enabled economic growth to improve domestic investment and exchange rate.

This analysis adopted in this study builds upon previous studies but provides both a broader perspective and deepens analysis of specific means of implementation. Moreover, be estimating a threshold level of inflation that is consistent with Nigeria's growth, this study provides a further insight on the inflation level that is effective to stimulate and enhance savings and investment. Following the introduction above, the remainder of the paper is organized as follows: Section 2 is literature review, section 3 methodology, section 4 is presentation and discussion of empirical results while section 5 is conclusion and recommendations.

\section{Literature Review}

Along with economic growth savings is considered as a major macroeconomic factor which has a strong relation with inflation. In a general equilibrium framework by Sidrauski (1967) it was found that money remained neutral in the time of steady state, implying that inflation has no impact on savings in the long run. There are however another argument that a negative relationship exist between inflation and savings. This conflicting view has thrown up further debate on inflation-saving interaction in the growth process. On the average GDP is an important indicator for the economy of a country. If GDP of a country increases with the faster rate than the population then it shows that GDP per capita of that country is increasing and standard of living of peoples is also improving. In recent years, discourse has been on among the economist and policy makers about the relationship between inflation and economic growth with some with the opinion that there is positive relationship between inflation and economic growth while others like World Bank (2012) posited that a negative relationship exist between inflation and economic growth. In the famous Philip's curve, it has been demonstrated that there exist a positive relationship between inflation and economic growth. This relationship was shown through the channel of aggregate demand and aggregate supply. In an economy, saving is considered very important factor for the improvement of an economy of a country. The conventional perception is that savings contribute to higher investment and hence higher GDP growth in the short run. Beside, it also plays an important role in the individual's life. It has been demonstrated that individuals who has more savings are more satisfied to face the adverse shocks. According to Modigliani, the rational people earn in the one part of their life such as in the working age and save money in this era for the older age. There are however other economists such as Keynes who believe that when the income of individual increase then the proportion of savings will also increase. The association between economic growth and the savings is not only most important but has also received considerable attention among researchers and analyzed this dilemma as cause and outcome relationship. Although Earbaykal and Okuyan (2008) have confirmed the positive relationship between savings and growth, a different category favors the capital fundamentalist point of view that savings cause growth while others are in favors of Keynesian theory that growth is necessary for savings.

Various strands of literature exist on the nexus among inflation, savings and economic growth. A famous study by Davidson and Mackinnon (1982) investigated the relationship between inflation and savings rate for the economy of America and Canada. Employing the chow test the study found that high inflation leads to high savings and unanticipated inflation leads to involuntary savings. In another study, Sahoo (2001) found that higher economic growth is necessary for increasing the savings of a country, thus supporting the traditional thesis that savings had been the engine of the economic growth. On the contrary Sheggu (2004), in a study conducted for Ethiopia economy, a bidirectional causality was exhibited between savings and economic growth. In another study to determine the impact of high inflation on economic growth both in the short-run and long-run, Faria and Carneiro (2001) employed VAR model and found that inflation had negative impact on economic growth in the short run while no relationship was found between inflation and economic growth in the long run. The study showed that although a negative relationship exist between inflation and economic growth, a 9 percent rate of inflation is tolerable for Pakistan economy beyond which the economy may experience harmful and detrimental growth. In a panel analysis of South east and South Asian countries, Chaturvedi, Kumar and Dholakia (2009) examined the inter-relationship among economic growth, savings and inflation and found that saving promotes economic growth. Also inflation was positively related to saving but negatively related to economic growth. However, in a specific country study for Pakistan, Muhammad, Hazoor, Shehzad and Naeem (2012) aptly repudiated that inflation and real interest rate negatively affect economic growth, whereas depreciation rate positively affect the economic growth. The result further shows that economic growth and foreign direct investment are beneficial for enhancing the savings of a country while depreciation rate is harmful for savings. Ramesh (2011) examined the direction of the relationship between saving, investment and economic growth in India at both aggregate level and sectoral level for the period 1950/51 to 2007/08 using Granger causality test through VAR/VECM framework. Besides, cointegration test based on JohansenJuselius (1990) method was used to test the long-run relationship among the variables. The cointegration test result suggests that there exist co-integration relationship among all series with GDP except private corporate saving. The study also found that the direction of causality runs 
from saving and investment to economic growth collectively as well as individually and there is no causality from economic growth to saving and (or) investment. Although, a reciprocal causality exists from saving and investment of the private sector to economic growth, this causality comes from the household sector where saving and investment led growth and growth driven saving and investment were observed. In the examination the effect of inflation in the growth process of an economy, Dewan and Hussein (1990), Barro (1995), Mishkin (2000), Ahmed and Murtatza (2005), Akerlof, Dickson and George (2006), Hussain and Malik (2011), Bruno and William (2012) was able to demonstrate that high level of inflation is harmful to savings and capital accumulation and economic, most especially for import-dependent economies. Another strand of literature, studies also examined foreign direct investment and economic growth linkage. One of such was conducted by Verma and Wilson (2005) for Indian economy using annual time series from 1950-2001. The finding showed little evidence that savings and investment affect GDP in the long run while GDP has significant but small effects on household savings and investment in the short run. The feedbacks to GDP are absent in the long run and only small and not precise in the short run. While savings influences investment, the links from investment to output are weak. Other studies in this area include Chung, Chung and Zhang (1995) for Chima, Egbor and Onwumere (2011) for Nigeria. A major conclusion arrived by these studies is that a positive link exist between investment and economic growth, although they have not been able to reinforce each other significantly due to unfavorable investment climate.

\section{Methodology}

Data employed by this study are annual time series covering 1980-2013 and they are generated from Central Bank of Nigeria Statistical Bulletin. For robustness of analysis, variables under consideration are economic growth (proxied by gross domestic product), savings rate, inflation rate, interest rate, exchange rate, unemployment rate, domestic investment and foreign domestic investment. Building on previous studies such as Chaturvedi, et al (2009) and Muhammad, et al (2012), this paper develops and adopts a simultaneous equation model and the formal structure of the model can be expressed as:

$$
\begin{aligned}
& \text { GDPt }=\mathrm{f}(\text { SVt, IFt, IRt, DRt, UPt, DIt, FDt }) \\
& \mathrm{SVt}=\mathrm{f}(\text { GDPT, IFt, IRt, DRt, DIt, FDt }) \\
& \mathrm{IFt}=\mathrm{f}(\text { GDPt, SVt, UPt, IRt })
\end{aligned}
$$

In linear form, equations (1) - (3) can be written as:

$$
\begin{array}{r}
\mathrm{GDPt}=\alpha_{1} \mathrm{SVt}+\alpha_{2} \mathrm{IFt}+ \\
\left.\mathrm{SVt}=\varphi_{1} \mathrm{GDPT}+\varphi_{2} \mathrm{IFt}+\varphi_{3} \mathrm{IRt}+\varphi_{4} \mathrm{ERt}+\varphi_{5} \mathrm{DIt}+\varphi_{6} \mathrm{FDt}\right) \\
\mathrm{IFt}=\chi_{1} \mathrm{GDPt}+\chi_{2} \mathrm{SVt}+\chi_{3} \mathrm{UPt}+\chi_{4} \mathrm{IRt}
\end{array}
$$

where $\alpha_{1-} \alpha_{:} \varphi_{1-} \varphi_{7} ; \chi_{1-} \chi_{4}$ are parameters, economic growth (proxied by GDP), $\mathrm{SV}=$ savings rate, $\mathrm{IF}=$ inflationary rate, $\mathrm{ER}=$ exchange rate, $\mathrm{UP}=$ unemployment rate, $\mathrm{DI}=$ domestic investment, FD = foreign direct investment, unemployment rate, domestic investment and foreign direct investments are included in the model as control variables.

A further extension of this study is the estimation of the threshold level of inflation consistent with Nigeria's growth The essence of this is to determine the point of inflexion or non-linear relationship between economic growth and inflation. Using a threshold model, Ahmad (2005) and Khan and Senhadji (2011) estimated the threshold level of inflation for Bangladesh. Relying heavily on the model, the subsequent equation for the estimation of the threshold level of inflation for Nigeria can be estimated as

$$
\operatorname{Ln} G D P_{t}=\beta_{0}+\beta_{1} I F_{t}+\beta_{2} D I F_{t}-K+\varepsilon
$$

In that above equation, economic growth and inflation ware computed as: $\operatorname{Ln} G D P_{\mathrm{t}}=$ economic growth, $I F_{t}=$ inflation rate (percentage annually) respectively. $\mathrm{D}$ is the dummy variable defined as follows: $D=1$ if $I F>K$; and $=$ 0 if $I F \leq K$. K depicts the threshold level of the inflation at which structural break occurs and $\varepsilon$ is random error term. The threshold level of inflation would be ascertained at that point where the value of $\mathrm{R}^{2}$ is maximum. This implies that the value of threshold level which minimizes the residual

$$
\left.t+\alpha_{4} \mathrm{ERt}+\alpha_{5} \mathrm{UPt}+\alpha_{6} \mathrm{DIt}+\alpha_{7} \mathrm{FDt}\right)
$$

sum of squares (RSS) would be selected. To do this, the method of ordinary least square (OLS) is employed.

\section{Presentation and Discussion of Results}

The empirical result entails the presentation of the descriptive statistics, 2-stage least square and inflation threshold. The descriptive statistics of the variables under consideration is presented in Table 1 below.

Table 1. Descriptive Statistics.

\begin{tabular}{lll}
\hline Variable & Mean & Standard Deviation \\
\hline Gross domestic product & 1701.67 & 221.9 \\
Savings rate & 154.24 & 58.9 \\
Inflation rate & 9.92 & 1.2 \\
Exchange rate & 29.07 & 4.5 \\
Interest rate & 42.16 & 9.8 \\
Unemployment rate & 56.85 & 3.8 \\
Domestic investment & 50.00 & 5.5 \\
Foreign direct investment & 62.87 & 18.9 \\
\hline
\end{tabular}

Table 2. The result of structural parameters of GDP growth rate.

\begin{tabular}{llll}
\hline Variables & Coefficients & $\begin{array}{l}\text { Standard } \\
\text { error }\end{array}$ & t-statistics \\
\hline C & 0.1209 & 0.00121 & 0.0001 \\
SV & 0.1213 & 0.0621 & 1.5500 \\
IF & -0.5231 & 0.0145 & -.2 .0190 \\
IR & -0.6201 & 0.1089 & -2.2348 \\
\hline
\end{tabular}

$\mathrm{R}^{2}=0.7624$ 
Table 3. Parameter estimates of Savings rate.

\begin{tabular}{lllll}
\hline Variables & Coefficients & $\begin{array}{l}\text { Standard } \\
\text { error }\end{array}$ & t-statistics & Probability \\
\hline C & 0.1245 & 0.0231 & 0.1012 & 0.0012 \\
GDP & 5.1082 & 0.5472 & 2.3401 & 0.0331 \\
IR & -0.0130 & 0.3122 & -0.8721 & 0.0235 \\
DR & 0.2311 & 0.1121 & 2.3400 & 0.2109 \\
FI & 5.1230 & 0.7612 & 5.6012 & 0.0514 \\
ER & -4.3412 & 1.7613 & 2.5632 & 0.0233 \\
\hline
\end{tabular}

$\mathrm{R}^{2}=0.6702$

Table 4. Parameter estimates of Inflation rate.

\begin{tabular}{lllll}
\hline Variables & Coefficients & $\begin{array}{l}\text { Standard } \\
\text { error }\end{array}$ & t-statistics & Probability \\
\hline C & 0.1245 & 0.0134 & -2.1012 & 0.1290 \\
GDP & 0.3452 & 0.3241 & 0.4531 & 0.0213 \\
SV & -0.8231 & 0.4452 & 0.3452 & -0.5020 \\
UR & -0.9912 & 0.4512 & -2.1239 & 0.0089 \\
IR & -0.7823 & 0.0671 & -9.1232 & 0.0202 \\
\hline
\end{tabular}

$\mathrm{R}^{2}=0.8723$

Table 5. Threshold level of inflation consistent with Growth.

\begin{tabular}{|c|c|c|c|c|c|}
\hline $\mathbf{K}$ & Variables & Coefficient & $\begin{array}{l}\text { Standard } \\
\text { error }\end{array}$ & t-statistics & $\mathbf{R}^{2}$ \\
\hline \multirow{3}{*}{5 percent } & Constant & 20.2130 & 0.2009 & 23.1098 & \multirow{3}{*}{0.1230} \\
\hline & $I F$ & -.0 .0234 & 0.0021 & -0.1209 & \\
\hline & $\Delta$ (Dummy) & 0.0341 & 0.1412 & 0.15612 & \\
\hline \multirow{3}{*}{6 percent } & Constant & 18.2123 & 0.1801 & 102.02 & \multirow{3}{*}{0.1094} \\
\hline & $I F$ & 0.0023 & 0.0023 & -1.2310 & \\
\hline & $\Delta$ (Dummy) & 0.2543 & 0.1012 & 0.1240 & \\
\hline \multirow{3}{*}{7 percent } & Constant & 17.6701 & 0.0345 & 99.012 & \multirow{3}{*}{0.2310} \\
\hline & $I F$ & -0.0342 & 0.1209 & -1.3421 & \\
\hline & $\Delta$ (Dummy) & 0.2390 & 0.0023 & 0.8901 & \\
\hline \multirow{3}{*}{8 percent } & Constant & 17.1230 & 0.0982 & 100.19 & \multirow{3}{*}{0.5612} \\
\hline & $I F$ & -0.0124 & 0.0912 & -1.4543 & \\
\hline & $\Delta$ (Dummy) & 0.1210 & 0.9801 & 0.9231 & \\
\hline \multirow{3}{*}{9 percent } & Constant & 18.1098 & 0.0231 & 102.123 & \multirow{3}{*}{0.1089} \\
\hline & $I F$ & -0.0234 & 0.1901 & -2.2435 & \\
\hline & $\Delta$ (Dummy) & 0.2331 & 0.3210 & 1.2310 & \\
\hline 10 percent & $\begin{array}{l}\text { Constant } \\
I F \\
\Delta \text { (Dummy) }\end{array}$ & $\begin{array}{l}18.2109 \\
-0.0234 \\
0.2390\end{array}$ & $\begin{array}{l}0.3012 \\
0.0023\end{array}$ & $\begin{array}{l}102.09 \\
-1.3248 \\
1.4323\end{array}$ & 0.0981 \\
\hline 11 percent & $\begin{array}{l}\text { Constant } \\
I F \\
\Delta \text { (Dummy) }\end{array}$ & $\begin{array}{l}18.2109 \\
-0.0254 \\
0.2390\end{array}$ & $\begin{array}{l}0.3012 \\
0.0023\end{array}$ & $\begin{array}{l}102.09 \\
-1.3248 \\
1.4323\end{array}$ & 0.0129 \\
\hline 12 percent & $\begin{array}{l}\text { Constant } \\
I F \\
\Delta \text { (Dummy) }\end{array}$ & $\begin{array}{l}18.0989 \\
-0.0034 \\
0.2221\end{array}$ & $\begin{array}{l}0.3011 \\
0.0011\end{array}$ & $\begin{array}{l}100.00 \\
-1.098 \\
1.2100\end{array}$ & 0.1902 \\
\hline
\end{tabular}

From the descriptive statistics, economic growth, savings rate, inflation rate, exchange rate, interest rate, unemployment, domestic investment and foreign direct investment exhibited respective average value of $170,154,9$, $29,42,57,53,50$ and 63 . The standard deviation shows that the observed variables vary so much from the average figure. The coefficient of inflation in Table 2 indicates that 1 percent increase in the prices leads to a 52 percentage reduction in economic growth. The result further shows that there is positive relationship between savings and economic growth. The coefficient of interest rate is an indication that higher interest rate endangers economic growth. This can be explained by the fact that during increase in real interest rate people prefer to deposit their money in the banks rather than investment which will ultimately retard economic growth. The result has also shown that a positive relationship exist between exchange rate and economic growth. The implication of this is that depreciation of currency has the ability of enhancing the exports of that country because now exports become cheaper. With increased demand of exports, domestic investors will increase the production of goods, given all other things. This will result in increase in economic growth. As indicated in Table 3, about 67 percent variation in savings in Nigeria is ascribed to inflation, economic growth and foreign direct investment. The calculated coefficient for economic growth depicts that it has significant impact of economic growth. This is a justification of the positive relationship between output and savings. With increased economic growth, incomes will be enhanced and ultimately savings will improve. The result is in tandem with the Keynesian theory which postulates that savings depend on the level of output. Similar conclusion was also reached by Modigliani (1970) and Jappelli and Pagano (1994). However, the negative sign of inflation is an indication that an inverse relationship exist between savings and inflation. The result further shows that there is a positive relationship between foreign direct investment and saving rate. This can be explained by the fact that that foreign capital inflow increased the supply of funds for investment thus enhancing the capital accumulation in host country. Increased investment stimulates economic growth and consequently saving rate would increase. In Table 4 above, the result shows that economic growth has significant impact on inflation. Specifically, a 1 percentage increase in economic growth led to 62 percentage reduction in the rate of inflation. This result supports the findings of Barro (1995). When savings rate was regressed on the inflation rate, it is found that savings rate has no significant impact on prices. However, a positive relationship exists between the variables analyzed. The negative relationship found between unemployment and the prices can be explained by the fact that with increased unemployment it means that people have less money so the demand of goods and services decreased and as a result inflation also decreases. The coefficient of real interest rate also shows the significant impact of real interest rate on the price level. The negative sign of the coefficient shows that there exist negative relationship between inflation and interest rate. The justification of negative relationship is that in general it has been seemed that when interest rate is low then people can borrow more money. As a result the purchasing power of the consumers will increase and may result to a situation where too much money is chasing too few goods in the economy.

For the threshold level of inflation that is consistent with Nigeria's growth, the OLS procedure was repeated severally in order to arrive at an acceptable $\mathrm{R}^{2}$. The estimated $\mathrm{R}^{2}$ and residual sum of square were taken into account and the assumed values of $\mathrm{K}$ covering from 1 to 27 . However, taking into consideration the value of residual sum of square and the 
value of $\mathrm{R}^{2}$ the anticipated results have been presented given tables for the $\mathrm{K}$ values ranging from 5 percent to 12 percent and the result is presented in Table 5. The result shows that 8 percent rate of inflation is tolerate able for Nigeria's economic growth. This is point where the value of $\mathrm{R}^{2}$ is maximum and residual sum of square is minimum. This implies that the model is best fit at 8 percent level. The value of probability also shows that the two variables significantly affected each other in the long run. However, the sign of the coefficient remained negative at all the $\mathrm{K}$ levels. This outcome confirmed the theoretical postulation that a double digit inflation rate is harmful and detrimental to economic growth.

\section{Conclusion}

In this study, it has been established that the key gamut to ensuring growth sustainability is to improve domestic savings and reduce inflation. Based on the simultaneous equation model developed, the study found that there exist bi-directional causality between inflation and economic growth, although they negatively affect each other in the long run. The analysis also found that indirect taxes have positive relation with prices whereas unemployment and real interest rate are negatively correlated with inflation. The results of the study further show that GDP growth and foreign direct investment has positive effect on savings whereas exchange rate decreases savings. The threshold level of inflation for economic growth was also estimated using OLS method and the result showed that at 8 percent rate of inflation, growth would be sustainable in Nigeria. There is need therefore for coordination among savings and economic growth policies as this will form the basis to improve investment in both public and private sectors of the Nigerian economy.

\section{References}

[1] Ahmad, S and M. G Murtatza (2005), "Inflation and Economic Growth in Banggledesh: 1981-2005", Working Paper Series: WP 0604, Policy Analysis Unit

[2] Akerlof, G. W, T. Dickson and I. P George (2006), "The Macroeconomics of Low Inflation", Brookings Paperon Economic Acivities, Vol. 1

[3] Barro, R. J (1995), "Inflation ane Economic Growth", Working Paper, 5326, Nation Bereau of Economic Research

[4] Bruno and William (2012), "Inflation and Long-run Growth", NBER Working Paper No: 5209 (Cambridge, Massachusetts, National Bureau of Economic Reearch)

[5] Chung, C, L. Chung and Y. Zhang (1995), "The Role of Foreign Direct Investment in China's Post 1978 Development", World Development, 23 (4)

[6] Chaturvedi, V. K and R. Dholakia (2009), "Inter-relationship between Economic Growth, Savings and Inflation in Asia", Indian Institute of Management Ahmadadad Working Paper No. 01
[7] Davison, D and J. Mackinnon (1982), "Inflation and Savings Rate", Queen's Economics Department Working Paper, No. 493

[8] Dan Haan, W. J (1990), "The Optimal inflation Path in a Sidrauski-Type Model with Uncertaintity", Journal of Monetary Economics, Vol. 28

[9] Dewan, E and S. Hussein (2001), "Detreminants of Economic Growth”, Working Paper, Reserve Bank of Fiji

[10] Eabaykai, E and H. Okuyan (2008), "Does Inflatiin depress Economic Growth? Evidence from Turkey", International Research Journal of Finane and Economics

[11] Egbo, O and J. Onwumere (2011), "Analysing the impact of Foreign direct investment on Nigeria's Economic Growth: A Cointegration approach", International Journal of Research and Management, Vol. 3: 78-97

[12] Faria, J and F. Carneiro (2001), "Does High Inlation affect Economic Growth in the Long and Snort run?", Journal of Applied Economics, 4 (1): 89-105

[13] Gbosh, A and P. Steven (1998), "Inflation, Disinflation and Growth" International Monetary Fund,Working Paper, $\mathrm{WP} / 98 / 68$

[14] Hussain, S and S. Malik (2011), "Inflation and Economic Growth: Evidence from Pakistan", International Journal of Economics and Finance, 3 (5): 32-54

[15] Institute of Policy Analysis and Research (IPAR) (2014), Policy Brief. Vol 11, Issue 2

[16] Jappeli, T and M. Pagano (1994), "Saving, Growth and Liquidity Constraints", The Quaterly Journal of Economics, Vol. 109 (1): 83-109

[17] Khan, M and D. Sinhadji (2001), "Threshold Effects in the Relationship between Inflation and Economic Growth", International Monetary Fund Staff Paper, Vol.48(1)

[18] Malik, G and A. Chowdhury (2001), "Inflation and Economic Growth: Evidence from four South Asian Countries", AsiaPercific Development Journal, Vol. 8 (1): 121-135

[19] Mishkin, F.S (2000), "Inflation Targeting in Emerging Market Countries", NBER Working Paper No: 7618 (Cambridge, Massachusetts, National Bureau of Economic Reearch)

[20] Modigliani, F (1970), The life cycle hypothesis of savings and inter-country difference in the saving ration, In: Eltis, W.A, M.F Scott and J.N Wolfe (eds), Introduction to Trade and Growth essay in honor of Sir Roy Harrod, London, Clarendon Press

[21] Muhammad, Hazoor, Shehzad and Naeem (2012), "The interrelationship among Inflation, Savings and Economic growth in Pakistan"

[22] National Bureau of Statistics (2012), Nigeria Economic Outlook, Federal Ministry of Finance, Abuja

[23] Verma, R and E. Wilson (2005), "Savings, Investment, Foreign Inflows and Economic of the Indian Economy, 1950200 Economic Working Paper Series, University of Wollongong

[24] Rosegrant, V and S. Evenson (1992), "Agriculture Investment and Productivity in Developing Countries", American Journal of Economics, Vol. 74 (3): 757-761 
[25] Sheggu, D (2004), "Causal Relationship between Growth and Gross Domestic Savings: Case of Ethiopia", Second International Conference on the Ethiopian Economy organized by Ethiopian Economic Association
[26] World Bank. (2012), World Development Report 1995:Workers in an Integrating World. Washington, D. C.: Oxford University Press for the World Bank. 